Борданова Л.С.

канд. економ. наук

Рощина Н.В.

канд. економ. наук, дочент

Начіональний технічний університет України «КПІ»

\title{
ОСОБЛИВОСТІ ПРОЦЕСУ ПРАЦЕВЛАШТУВАННЯ МОЛОДІ НА РИНКУ ПРАЦІ
}

\author{
ОСОБЕННОСТИ ПРОЦЕССА ТРУДОУСТРОЙСТВА МОЛОДЕЖИ НА \\ РЫНКЕ ТРУДА
}

\section{FEATURES OF THE PROCESS OF YOUTH EMPLOYMENT IN THE LABOR MARKET}

У статті досліджено особливості прочесу працевлаштування молоді на ринку прачі, а саме: уточнено сутність поняття «прачевлаштування молоді» та визначено основні чинники впливу на означений процес. Отже, аналіз суб'єктно-об'єктних відносин процесу працевлаштування молоді на ринку праці надало можливість визначити його зміст як сукупність соціально-економічних та інституційно-правових заходів, щзо реалізуються за безпосередньої активної участі молодi, відповідних державних та недержавних органів і спрямовані на забезпечення продуктивної зайнятості та гідних умов праці для молоді, а також створення передумов для ї̈ розвитку. Оскільки ключовим аспектом проведеного дослідження $\epsilon$ розгляд основних чинників впливу на процес прачевлаштування, авторами було запропоновано їх класифікацію, яка дає можливість забезпечити адресність дій щуодо регулювання працевлаштування молоді на ринку праці. Крім того, у роботі виокремлено стадії процесу працевлаштування молоді на ринку праці.

Ключові слова: молодь, ринок праці, працевлаштування молоді, стадії процесу працевлаштування, чинники впливу.

В статье исследованы особенности процесса трудоустройства молодежи на рынке труда, а именно: уточнена сущность понятия «трудоустройство молодежи» и определены основные факторы влияния на указанный процесс. Таким образом, анализ субъектнообъектных отношений процесса трудоустройства молодежи на рынке труда дало возможность определить его содержание как совокупность социально-экономических и институционально-правовых мер, реализуемых при непосредственном активном участии молодежи, соответствующих государственных и негосударственных органов и направленные на обеспечение продуктивной занятости и достойных условий труда для молодежи, а также создание предпосылок для ее развития. Поскольку ключевым аспектом проведенного исследования является рассмотрение основных факторов влияния на процесс трудоустройства, авторами была предложена их классификация, которая дает возможность обеспечить адресность действий по регулированию трудоустройства молодежи на рынке труда. Кроме того, в работе выделены стадии процесса трудоустройства молодежи на рынке труда.

Ключевые слова: молодежь; рынок труда; трудоустройство молодежи; стадии 
процесса трудоустройства, факторы влияния.

The paper clarified the essence of the concept of "youth employment", the factors affecting youth employment. It was found that the essence of the process of youth employment in the market is a combination of proposals on the youth labour market and the demand of employers. The study of the subject-object relationship of the process of youth employment in the labour market helped to define the content of the process of youth employment as a set of socio-economic and institutional and legal activities carried out with the direct active participation of young people, relevant government and non-government bodies and aimed at providing productive employment and decent work for young people, and create conditions for its development. The classification of factors influencing youth employment, which allows for targeted action to manage the employment of young people in the labour market. Highlighted stage of the process of youth employment in the labour market.

Keywords: young people; labour market; youth employment; the stage of the employment process.

Вступ. Сучасний ринок праці в Україні не в повній мірі виконує свої основні функції та потребує виваженого і гнучкого регулювання 3 метою усунення дисбалансу між потребою економіки в робочій силі та іi пропозицією. Однією 3 найбільш важливих i одночасно проблемних складових ринку праці є його молодіжний сегмент, що відображає основні тенденції розвитку економіки, освіти та ринку праці. Під час пошуку першого робочого місця пошукач досить часто зустрічається з невідповідністю рівня та якості отриманої освіти, відсутністю досвіду роботи, невідповідністю запитів молоді та пропозицій роботодавців і т.п. Все це посилює напруження на ринку праці та ускладнюють ефективне виконання ним своїх основних функцій. Таким чином, виникає нагальна потреба у врегулюванні процесу працевлаштування молоді 3 використанням методів та інструментів, що відповідають особливостям та тенденціям розвитку ринку праці.

Проблеми працевлаштування молоді та регулювання іiі зайнятості досліджено в працях вітчизняних та зарубіжних науковців О. Абашиної, О. Балакірєвої, Д. Богині, І. Бондар, М. Долішнього, О. Дяків, Л. Ільїч, Т. Заяць, С. Калініної, Т. Кір'ян, Е. Лібанової, Л. Лісогор, Н. Лук'янченко, Ю. Маршавіна, І. Петрової, В. Петюха, В. Рибалко, М. Хромова, Л. Шаульської, О. Яременко, Р. Джекмана, Р. Леярда, Т. Парсонса, Г. Стенлі, Р. Філера та інших. Утім, представлена тема дослідження $є$ вельми актуальною оскільки питання працевлаштування молоді в Україні залишається невирішеним. Більш того, останнім часом відбувається погіршення соціально-економічних умов, що призводить до ускладнення зазначеного процесу та потребує перегляду наявного інструментарію та чинників, що мають найбільш вагомий вплив на його складові.

Постановка завдання. Метою даної статті є визначення особливостей процесу працевлаштування молоді на ринку праці взагалі та в України 
зокрема. Відповідно до зазначеної мети завданнями статті $\epsilon$ уточнення сутності поняття «працевлаштування молоді» та визначено основні чинники впливу на означений процес.

Методологія. Теоретико-методологічну основу роботи становлять праці вітчизняних та зарубіжних вчених у сфері оцінювання ефективності діяльності підприємств. Для досягнення поставленої мети використано загальнонаукові та спеціальні методи дослідження, такі як: системний підхід, методи аналізу та синтезу - було використано для отримання основних результатів дослідження, прийоми логічного узагальнення - для підведення підсумків та написання висновків.

Результати дослідження. У економічній теорії працевлаштування розглядається як соціально-економічні відносини між найманими працівниками і роботодавцями щодо доступу перших до робочого місця $\mathrm{i}$ включення працівника в конкретну кооперацію праці на робочому місці [1, с.8]. Ці відносини розвиваються під впливом суперечностей, джерелом яких $\epsilon$ розбіжності економічних та соціальних інтересів, а носіями - суб'єкти відносин у цій сфері - роботодавці (власники засобів виробництва) і особи найманої праці (власники здатності до праці) [1, с.8].

Працевлаштування, що за своєю сутністю є укладанням угоди про купівлю-продаж робочої сили на ринку праці, $є$ логічною реалізацією виконання посередницької функції ринку праці. Оскільки молодіжний ринок праці має певні специфічні риси, у багатьох випадках працевлаштування молоді на ринку праці ускладнюється саме через ці особливості самого ринку та безпосередньої специфічного товару «робочої сили молоді».

Унікальність молодіжного ринку праці вимагає використання особливих підходів до регулювання процесу працевлаштування молоді, що перш за все потребує ретельно розгляду сутності категорії «працевлаштування». Згідно 3 трудовим правом працевлаштування трактується як у широкому, так і у вузькому розумінні.

У широкому значенні працевлаштування об’єднує всі форми трудової діяльності, що не суперечать законодавству, включаючи забезпечення себе роботою, у тому числі індивідуальну трудову діяльність, підприємництво, фермерство тощо. У вузькому значенні працевлаштування - це такі форми трудової діяльності, які встановлюються за сприяння органів держави або недержавних організацій на основі ліцензування [2, с.130].

У економічній літературі існує також інша точка зору на визначення працевлаштування в широкому та вузькому розумінні [3, с. 183]: у широкому розумінні воно розглядається як процес будь-якого влаштування на роботу, як самостійного, так i за допомогою служби зайнятості. Зокрема, це й переведення працівників за умов їх вивільнення на іншу роботу на тому ж підприємстві чи в організації. У вузькому розумінні працевлаштування - це 
діяльність відповідних державних органів зі сприяння громадянам України в пошуках потрібної роботи й процеси професійної підготовки, перепідготовки тощо.

Працевлаштування молоді розглядається науковцями як система спеціальних економічних та організаційно-правових заходів щодо забезпечення трудової зайнятості такої окремої категорії населення як молодь, що включає самостійне забезпечення роботою або забезпечення роботою 3 допомогою відповідних державних і недержавних органів [4, с.41].

Поняття «працевлаштування молоді» І.В. Хохряковою визначає як систему спеціальних економічних та організаційно-правових заходів відповідних державних і недержавних органів щодо забезпечення трудової зайнятості такої окремої категорії населення, як молодь [5, с.7].

На основі наявних підходів до визначення особливостей молодіжного ринку праці та сутності працевлаштування, працевлаштування молоді пропонуємо розглядати як сукупність соціально-економічних та інституційноправових заходів, що реалізуються за безпосередньої активної участі молоді, відповідних державних та недержавних органів і спрямовані на забезпечення ефективної зайнятості та гідних умов праці для молоді, а також створення передумов для iї розвитку. Працевлаштування молоді - це складний процес, що відображає суспільно-правові відносини між учасниками молодіжного ринку праці, які виникають під час пошуку потрібного робочого місця та влаштування на нього.

Відносини працевлаштування виникають у результаті пошуку роботи фізичною особою $\mathrm{i}$, як зазначено в юридичній літературі, становлять єдність трьох взаємопов'язаних, але відносно самостійних правовідносин: а) між органом працевлаштування і громадянином, який звернувся із заявою про влаштування на роботу; б) між органом працевлаштування і організацією, яка потребує кадрів; в) між громадянином і організацією, куди він направлений на роботу органом працевлаштування $[6$, с.8].

Дослідники визначають, що вирішальними чинниками під час працевлаштування молоді постають такі [7, с. 153]:

соціальні та професійні орієнтації молоді (соціально-професійний статус; рівень освіти, необхідний для оволодіння професією: сфера діяльності (розумова чи фізична праця) та галузь економіки: конкретна професія; форма власності підприємства чи організації);

мотиви професії (самореалізація та прояв здібностей; матеріальна забезпеченість; престиж та кар'єра; спілкування (робота в колективі, стосунки 3 клієнтами); зміст праці (інтерес до професії, творчий характер, результат праці, самостійність рішення; удосконалення навичок, умови праці, суспільна користь);

економічні орієнтації (оцінка соціально-економічних процесів у 
суспільстві та матеріального статусу родини, ставлення до багатства, безробіття, соціального розшарування суспільства; уявлення про наявні в суспільстві способи досягнення багатства тощо);

уявлення про життєвий успіх та способи його досягнення (життєво значущі цілі та основні способи їх досягнення, місце матеріального достатку в структурі життєво значущих цілей тощо);

економічна активність - досвід самостійних заробітків, регулярність економічної активності; ставлення до заняття бізнесом, комерцією та бажанням ними займатися; орієнтація на власний бізнес, свою справу; можливі дії в разі безробіття.

На нашу думку, різноманітні чинники, що впливають на працевлаштування молоді можуть бути розподілені на дві основні групи (рис.1): зовнішні (характеризують загальний стан сфери працевлаштування i державного впливу на ці процеси) та особистісні, що характеризують конкурентоспроможність молодої людини на ринку праці та розкривають іiі специфічні особливості як носія робочої сили. Зовнішні чинники, у свою чергу, включають такі: загальноекономічні, інституційно-організаційні, правові.

Необхідність класифікації чинників впливу обумовлена тим, що їх виокремлення за групами дозволяє здійснювати адресний управлінський вплив на кожний з чинників, що дозволить створити більш сприятливі умови для працевлаштування молоді.

Відносини суб’єктів молодіжного ринку праці щодо працевлаштування (місцеві органи влади; державна служба зайнятості; навчальні заклади; кадрові агенції; підприємства та організації; профспілки; спеціалізовані видання) мають багатовекторний характер і кінцевою метою визначають 


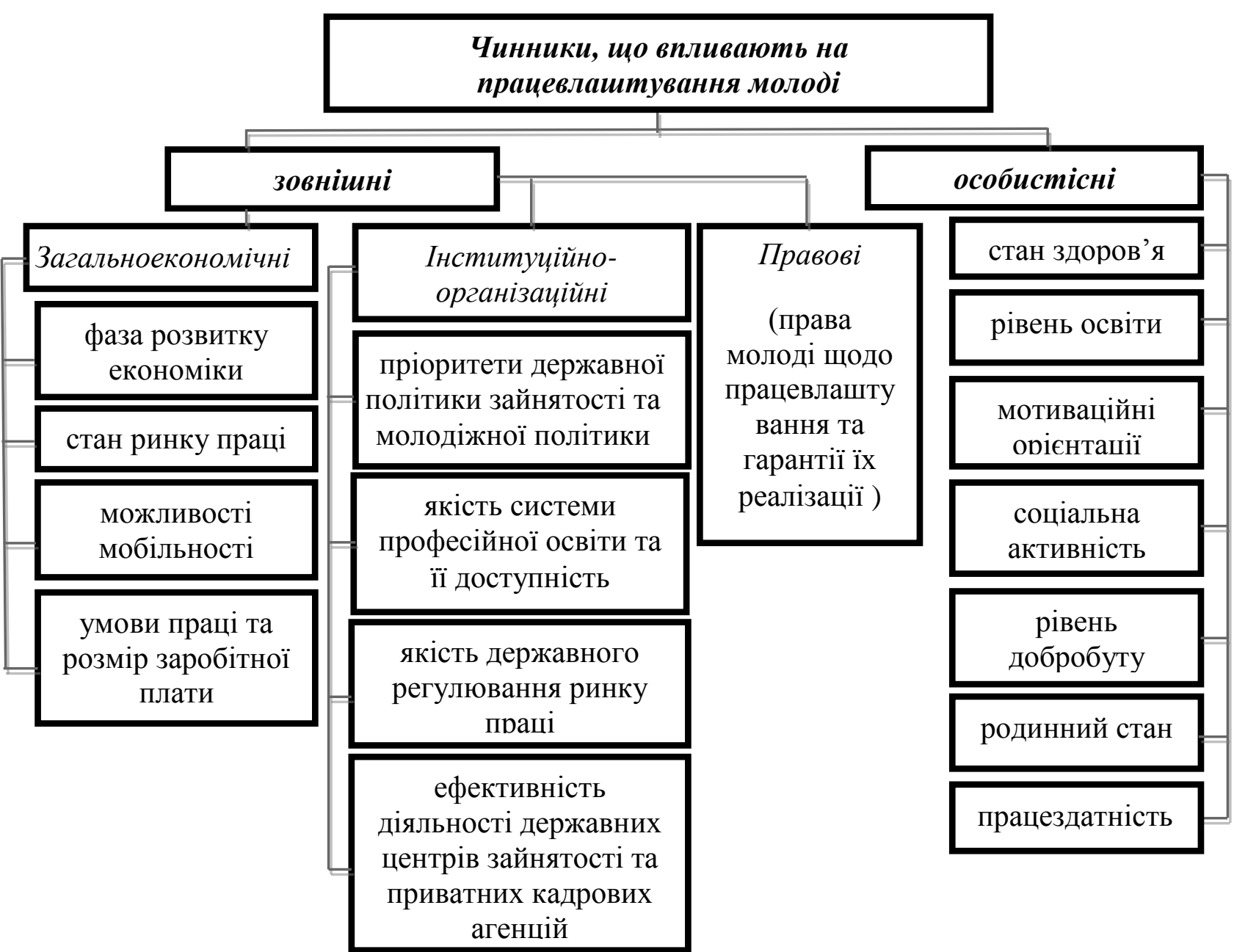

Рис. 1. Класифікація чинників, що впливають на працевлаштування молоді

збалансування попиту та пропозиції робочої сили у віці 16-35 років (рис. 2), тобто задоволення потреб економіки в робочі силі та прагнень молодої людини знайти сферу прикладання своєї праці та джерело отримання доходу.

M.M. Руженський зазначає, що суб'єкти працевлаштування в процесі взаємодії мають на меті власні економічні та соціальні інтереси, узгодження яких може дати позитивний результат. При цьому необхідно враховувати, що претендент на робоче місце повинен відігравати в процесі працевлаштування активну роль, стимулюючи свій розвиток, здібності та нахили у сфері трудової діяльності для того, щоб забезпечити власний соціальний захист [1, c.9]. 


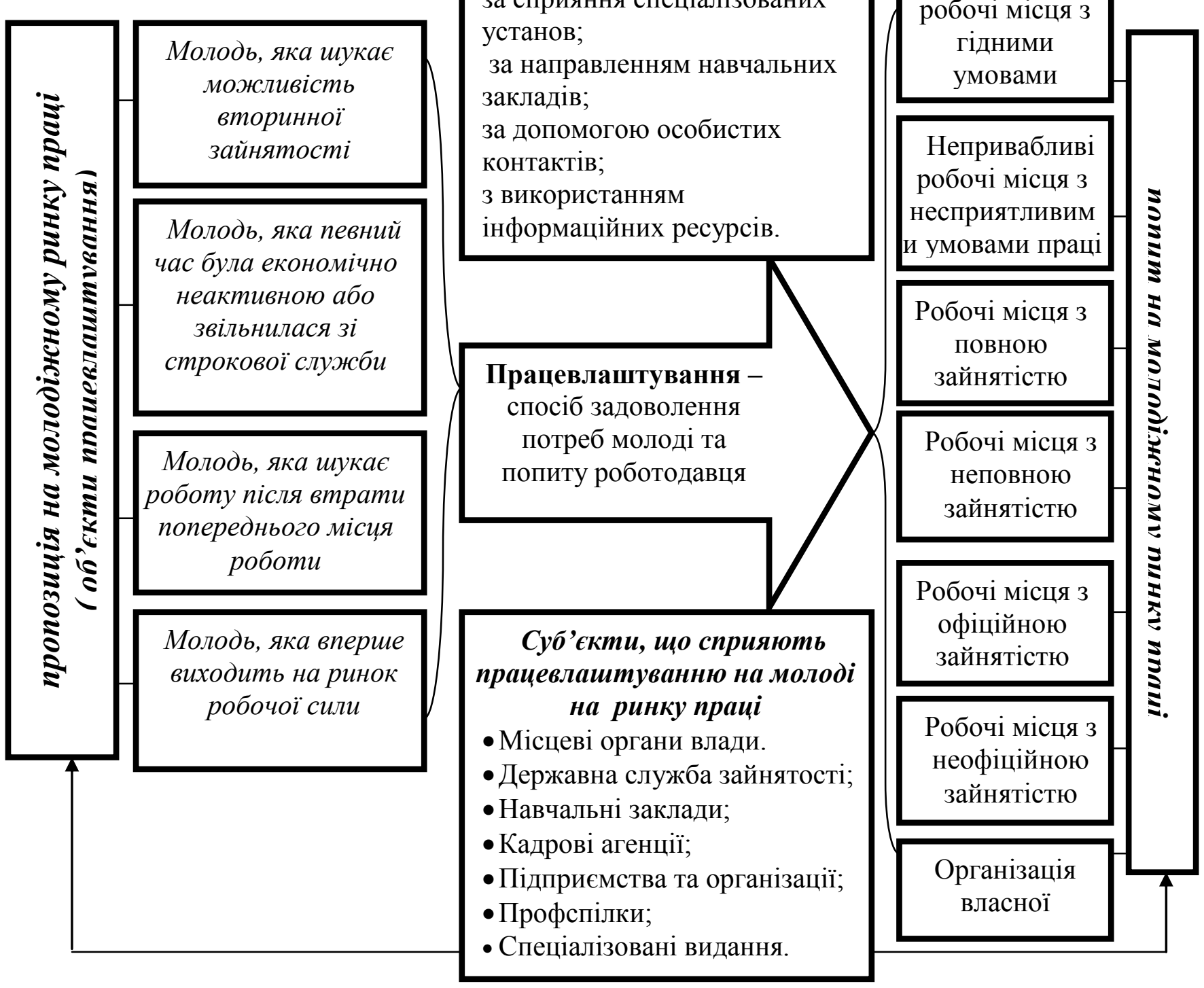

Способи працевлаштування:

за сприяння спеціалізованих

установ

за направленням навчальних

закладів;

за допомогою особистих

контактів;

з використанням

інформаційних ресурсів.

Робочі місця 3

офіційною

зайнятістю

Робочі місця з неофіційною зайнятістю

Організація власної

Рис. 2. Структурна схема суб'єктно-об'єктних відносин процесу працевлаштування молоді на молодіжному ринку праці

Наведене визначення $є$ справедливим й для працевлаштування молоді. Одним 3 векторів суб'єктно-об'єктних відносини процесу працевлаштування молоді на ринку праці є стимулювання працевлаштування молоді. У контексті трудових відносин, стимулювання працевлаштування

громадян, що є недостатньо конкурентоспроможними на ринку праці (у тому числі - молоді) І. В. Мартинюк визначає як невід'ємну частину національної соціальної політики, цілеспрямовану діяльність органів державної влади, спрямовану на створення економічних та правових підстав отримання такими громадянами потрібної роботи чи започаткування власної справи [8, с. 180]. 
На його думку, стимулювання працевлаштування осіб, що є недостатньо конкурентоспроможними на ринку праці має грунтуватись на таких принципах [8, сс. 181-182]:

1. Прозорість та доступність - за цим принципом стимули повинні бути зрозумілими для кожного роботодавця (підприємця) - активно проводиться роз'яснювальна робота серед власників підприємств, відповідні рішення (проекти рішень) оприлюднюються в засобах масової інформації.

2. Реальність та дієвість - стимул повинен передбачати реальні механізми реалізації, які, по-перше, відповідали б актуальному стану ринку праці, по-друге, розроблялися з урахуванням тенденцій розвитку економіки відірваність стимулів від сучасного стану речей не тільки знизить їх дієвість, а й підвищить тінізацію ринку праці.

3. Поступовість - роль стимулу полягає не тільки в тому, щоб надати матеріальну компенсацію роботодавцю за працевлаштування певних категорій осіб, а й сприяти їх подальшій праці на конкретному робочому місці. Тому незважаючи на максимальну дії стимулу за умови жорсткого зв'язку «виконав умови - отримав преференції», ефективніше розтягти в часі застосування заохочення, застосовувати його через певний період часу після виконання умов заохочення.

4. Взаємні гарантії сторін - зафіксовані державою гарантії отримання компенсації за умови виконання умов працевлаштування осіб, що $\epsilon$ недостатньо конкурентоспроможні на ринку праці протиставляються гарантіям роботодавця виплачувати зарплату не нижче визначеного розміру та не ініціювати припинення трудових відносин за власної волі протягом певного періоду часу. За порушення взаємних гарантій передбачена відповідальність: у разі невиконання гарантій роботодавцем, він повинен повернути отриману компенсацію; у разі невиплати цієї компенсації може захищати свої права в судовому порядку.

5. Комплексність та системність - за цим принципом визнається необхідність врахування всіх можливих чинників (організаційних, моральних, соціологічних, економічних, правових тощо) під час введення в дію стимулу. Застосування чинників не по одному, а в сукупності сприятиме найбільш оптимальному результату. У той же час потрібно постійно виявляти та усувати суперечності між чинниками, сприяти створенню системи стимулювання, яка $\epsilon$ внутрішньо збалансованою за рахунок взаємного узгодження їі елементів.

6. Регламентація - застосування стимулів повинне визначатися за допомогою різних інструкцій, положень, правил. Саме чітка регламентація прав і обов'язків сторін, закріплення їх на нормативному рівні сприятиме не декларативній, а реальній дії механізму стимулювання.

Оскільки молодь $є$ також неконкурентоспроможною категорією на 
ринку праці, визначені I. В. Мартинюк принципи $є$ справедливими й для молодіжного ринку праці та взаємодії його учасників.

На думку В.В. Безусого, процес працевлаштування можна розділити на дві стадії. Перша - підшукування роботи, друга - укладання трудового договору. Так, процес працевлаштування починається 3 того, що особа, яка бажає працювати звертається до органів, що опікуються працевлаштуванням, 3 метою сприяння в підшукуванні роботи або починає самостійно підшукувати собі роботу. До органів, які опікуються працевлаштуванням належать: Міністерство праці та соціальної політики України, державна служба зайнятості, місцеві державні органи, органи місцевого самоврядування, громадські організації, суб'єкти підприємницької діяльності $[6$, c.8].

На нашу думку, працевлаштування молоді $\epsilon$ набагато складнішим процесом і включає щонайменше 6 основних стадій:

1. Усвідомлення необхідності пошуку роботи та прийняття рішення щодо працевлаштування.

2. Вибір способу пошуку роботи (самостійно або із залученням третіх осіб).

3. Об'єктивна самооцінка власної конкурентоспроможності на ринку праці.

4. Збирання та аналіз оперативної інформації щодо стану ринку праці та наявних вакансій потрібної роботи.

5. Виконання практичних дій щодо отримання робочого місця (подання резюме, співбесіди, участь у професійних випробуваннях і конкурсах тощо).

6. Укладання трудової угоди (у разі офіційного працевлаштування) або усної домовленості (у разі неофіційного працевлаштування), щодо прийняття на роботу та визначення умов праці.

Висновок. Таким чином, дослідження особливостей процесу працевлаштування молоді на ринку праці взагалі та в України зокрема надало можливість встановити, що сутність суб'єктно-об'єктних відносин процесу працевлаштування молоді на ринку праці полягає в поєднанні пропозиції на молодіжному ринку праці та попиту роботодавців, a їх зміст визначається запропонованою структурною схемою. Представлений результат становить наукову новизну проведеного дослідження. Поряд 3 цим, він створює підгрунтя для виваженого регулювання працевлаштування молоді на регіональному ринку праці та формування відповідного інституційноорганізаційного забезпечення.

Крім того, до основних результатів роботи, що формують наукову новизну, необхідно додати запропоновану авторами класифікацію основних чинників впливу на процес працевлаштування молоді в сучасних соціальноекономічних умовах, яка дає можливість забезпечити адресність дій щодо регулювання зазначеного процесу. 
Перспективами подальших наукових досліджень $\epsilon$ виявлення особливостей становлення молодіжного ринку праці безпосередньо в Україні та основних проблем, що супроводжують зазначений процес.

\section{Лiтература:}

1. Руженський М. М. Працевлаштування як форма соціального захисту населення / М. М. Руженський // Ринок праці та зайнятість населення. - 2013. - № 2. - С. 8-11.

2. Болотіна Н.Б. Трудове право України: підручник / Н.Б.Болотіна, Г.І.Чанишева. - К.:Знання, 2000. -564 c.

3. Золотухіна Л. О. Перше працевлаштування за чинним Кодексом законів про працю та проектом Трудового кодексу України / Л. О. Золотухіна, М.А. Пивонос // Науковий вісник Дніпропетровського державного університету внутрішніх справ . - 2012. - № 3. - С. 181-186.

4. Щотова Ю.М. Правове регулювання працевлаштування молоді в Україні: монографія / Ю.М. Щотова. - К.:АПСВ, 2007. - 192 с.

5. Хохрякова I.В. Державне управління зайнятістю молоді в контексті формування нових державно суспільних відносин в Україні: автореф. дис. на здобуття наук. ступеня канд. наук з держ. управління: спец. 25.00.01 "Теорія та історія держ. управління" / І.В.Хохрякова. Дніпропетровськ, 2010. - 20 с.

6. Безусий В.В. Правове регулювання працевлаштування в Україні: автореф. дис. на здобуття наук. ступеня канд. юрид. наук.: спец. 12.00 .05 «Трудове право» / В.В.Безусий. Харків, 2007. 19 с.

7. Пасічніченко С. В. Соціальний захист молоді у сфері працевлаштування як знаряддя реалізації державної політики зайнятості / С. В. Пасічніченко // Соціальна робота в Україні: теорія і практика . - 2013. - № 12. - С. 151-161.

8. Мартинюк I. В. Поняття та значення стимулювання працевлаштування громадян, які є недостатньо конкурентоспроможними на ринку праці / I. В. Мартинюк // Митна справа. - 2013. - № 5(2.2). - С. 178-185. 